\title{
Acute Myeloid Leukemia with Biallelic Mutations of CEBPA
}

National Cancer Institute

\section{Source}

National Cancer Institute. Acute Myeloid Leukemia with Biallelic Mutations of CEBPA. NCI

Thesaurus. Code C129782.

An acute myeloid leukemia with double mutations of the CEBPA gene. 